\title{
Association between interleukin 6 promoter variants and chronic hepatitis B progression
}

\author{
Byung Lae Park', Hyo-Suk Lee ${ }^{2,3}$, \\ Yoon Jun $\mathrm{Kim}^{2}$, Jun Yeon Kim ${ }^{1}$, \\ Ji Hyun Jung ${ }^{1}$, Lyoung Hyo Kim ${ }^{1}$ \\ and Hyoung Doo Shin ${ }^{1}$
}

\author{
${ }^{1}$ Department of Genetic Epidemiology \\ SNP Genetics, Inc., $11^{\text {th }}$ Floor, Maehun B/D \\ 13 Chongro 4 ga, Chongro-gu, Seoul 110-834, Korea \\ ${ }^{2}$ Department of Internal Medicine and Liver Research Institute \\ Seoul National University College of Medicine \\ 28 Yungun-dong, Chonro-gu, Seoul 110-744, Korea \\ ${ }^{3}$ Corresponding author: Tel, 82-2-745-7557; \\ Fax, 82-2-744-8243; E-mail, hsleemd@snu.ac.kr
}

\section{Accepted 20 March 2003}

Abbreviations: $\mathrm{HBc}$, hepatitis $\mathrm{B}$ core antigen; HBs, hepatitis $\mathrm{B}$ surface antigen; $\mathrm{HCV}$, hepatitis $C$ virus; $\mathrm{HBV}$, hepatitis $B$ virus; HCC, hepatocellular carcinoma; LD, linkage disequilibrium; SBE, single base extension; SNP, single nucleotide polymorphism

\begin{abstract}
Interleukin 6 (IL6) plays an essential role in the regulation of immune response to chronic disease. In this study, the three known single nucleotide polymorphisms (SNPs) in the IL6 promoter region were genotyped in a large chronic hepatitis B cohort to evaluate the effects of IL6 promoter variants. The single base extension method was used for this genotyping. Haplotypes were constructed by the three SNPs in IL6. Allele frequencies were compared for; i) patients with chronic hepatitis (CH) and chronic carriers vs. chronic hepatis patients with clinical evidence of liver cirrhosis (LC) (i.e., portal hypertension), ii) cirrhotic patients with hepatocellular carcinoma (HCC) vs. without HCC by logistic regression, and iii) with respect to the time intervals from the onset of infection to HCC. Results were analyzed by Cox relative hazard analysis on the assumption that all the patients were infected during early infancy. The frequencies of each SNP were 0.002 (IL6-597 G>A), 0.25 (IL6-572 $C>G$ ) and 0.002 (IL6-174 G>C), respectively, in the Korean population $(n=1,046)$. No significant associations were detected between IL6-572 C> G and chronic hepatitis $B$ outcome in this study; i.e.,
\end{abstract}

LC occurrence on $\mathrm{CH} \quad(\mathrm{OR}=0.16-1.27, P=0.13$ $0.71)$ and HCC occurrence on LC (OR $=1.04-1.23$, $P=0.89-0.60)$ of heterozygotes and homozygotes for $G$ allele in referent comparison to homozygotes for common allele (C/C genotype), and time interval to $\mathrm{HCC}(\mathrm{RH}=0.67-1.00 ; P=0.14-0.99)$. In conclusion, there appeared to be no significant associations between IL 6 promoter variants and disease outcome in chronic hepatitis B.

Keywords: carcinoma, hepatocellular; haplotypes; hepatitis B virus; interleukin-6; polymorphism, single nucleotide; promoter regions (genetics)

\section{Introduction}

Korea is an endemic area of chronic hepatitis $B$ virus (HBV) infection. The sequelae of chronic HBV infection vary from an inactive carrier state to the development of cirrhosis and hepatocellular carcinoma (HCC). Chronic carriers of HBV have a high risk of developing HCC compared with uninfected individuals (Blumberg, 1984; Huh et al., 1998; Merican et al., 2000). HCC is the most common primary liver cancer and is one of the ten most common carcinomas in the world. The incidence of HCC shows geographical variation and is most common in Asia and Africa, where HBV infection is highly endemic and where chronic infection is usually acquired in early infancy (Yu et al., 2000a). Typically, the development of HCC occurs 30-50 years after the onset of HBV infection; consequently $\mathrm{HCC}$ is far more likely to be seen in individuals exposed to HBV perinatally rather than horizontally in adult life.

The outcomes of HBV infection do not appear to be determined by the viral strains in themselves (Cacciola et al., 2002). However, the factors involved in the progression of chronic HBV infection to LC and to HCC among chronic HBV carriers require investigation. It has been established through twin studies that chronic HBV infection outcome has a strong genetic component (Shimbo et al., 1997). Moreover, allelic variants in the human genome, e.g., N-acetyltransferase (Yu et al., 2000b), vitamin D receptor (Bellamy et al., 1999), and HLA (Almarri and Batchelor, 1994) have been implicated in disease progression after HBV infection (Thursz, 1997; Thursz, 2001).

Interleukin 6 (IL6) is a multifunctional cytokine es- 
sential for the regulation of immune response (Kakumu et al., 1993; Galun et al., 2000). It exerts its actions by binding to its cell-surface receptor. Serum levels of IL6 were found to be significantly increased in patients with chronic hepatitis B (Malaguarnera et al., 1997; Song et al., 2000) and in patients with chronic hepatitis C patients (Wang et al., 1999). However, the association between polymorphisms of IL6 gene and chronic hepatitis $B$ progression has not been studied, nonetheless the importance of IL6 in conjunction with progression of chronic hepatitis disease remains.

In the present study, as one of efforts to discover additional polymorphism(s) in genes of which variant(s) have been implicated in chronic hepatitis $B$ progression, we examined the genetic effects of the all of the three known polymorphisms in the IL6 promoter $(-597 \mathrm{G}>\mathrm{A},-572 \mathrm{C}>\mathrm{G},-174 \mathrm{G}>\mathrm{C})$ by identifying the naturally occurring haplotypes in a large scale HBV cohort.

\section{Material and Methods}

\section{Study subjects and serological tests}

1,046 Korean subjects were enrolled at an out-patient liver unit clinic and at the Center for Health Promotion at Seoul National University Hospital between January 2001 and August 2001. Subjects were categorized into three groups: chronic hepatitis $(\mathrm{CH}), \mathrm{LC}$ and HCC. All patients included in this study were hepatitis $B$ surface antigen (HBsAg) positive over a 6-month period. Patients who were positive for anti- HBs without anti-HBc (serological status by hepatitis B vaccination), and patients who were positive for anti-HCV or antiHIV were excluded. Informed consents were obtained from each patient, and the Institutional Review Board for Human Research at Seoul National University Hospital approved the study protocol. The characteristics of the subjects are shown in Table 1.

Serologic tests were performed on every subject

Table 1. The characteristics of subjects.

\begin{tabular}{|c|c|c|c|c|c|}
\hline \multirow{2}{*}{ Groups* } & \multicolumn{3}{|c|}{ No. of subjects } & \multicolumn{2}{|c|}{ Age $( \pm S D)$} \\
\hline & Total & Male & Female & Male & Female \\
\hline $\mathrm{CH}$ & 295 & 227 & 68 & $46.4( \pm 0.9)$ & $49.2( \pm 8.9)$ \\
\hline LC & 514 & 371 & 143 & $49.1 \quad( \pm 8.6)$ & $52.3( \pm 9.6)$ \\
\hline $\mathrm{HCC}$ & 237 & 193 & 44 & $56.2( \pm 8.56)$ & $53.1( \pm 9.6)$ \\
\hline Total & 1046 & 791 & 255 & $50.0( \pm 10.0)$ & $51.6( \pm 9.5)$ \\
\hline
\end{tabular}

${ }^{*} \mathrm{CH}$, chronic hepatitis; LC, liver cirrhosis; HCC, hepatocellular carcinoma. using commercially available products for $\mathrm{HBsAg}$ (Enzygnost HBsAg 5.0, Dade Behring, Marburg, Germany), anti-HBs (Enzygnost Anti-HBs II) and antiHBc (AB-Corek, DiaSorin s.r.l., Saluggia, Italy). Patients who were positive for anti-HCV or anti-HIV by ELISA (GENEDIA, Greencross Life Science Corp., Yongin-shi, Korea; HCV3.2, Dong-A Pharmaceutical Co., Seoul, Korea, respectively) and patients whose average alcohol consumption assessed by interview was $\geq 10 \mathrm{~g} / \mathrm{day}$ were excluded (Yu et al., 1988). The consumption and types of alcohol drinking were asked and the alcohol content of each drink was calculated. Weekly alcohol intake was converted into alcohol g/ day. Patients having any other types of liver disease, such as autoimmune hepatitis, toxic hepatitis, primary biliary cirrhosis or Budd-Chiari syndrome were excluded. We also excluded subjects who had a previous history of immunosuppression or anti-viral treatment. The diagnosis of HCC or LC was made as described previously (Lee et al., 1993).

\section{Genotyping of SNPs in the IL6 promoter region}

All of the three known single nucleotide polymorphisms (SNPs) in the IL6 promoter region were genotyped. The locations of these SNPs in relation to the genomic structure of the IL6 gene are shown in Figure 1. Sequences of amplifying and extension primers for SNP genotyping using the single base extension method for IL6-597 $\mathrm{G}>\mathrm{A}$, IL6-572 $\mathrm{C}>\mathrm{G}$ and IL6-174 $\mathrm{G}>\mathrm{C}$ were forward 5'-GCAAAGTCCTCACTGGGAGGA-3', reverse 5'-GGGCTGCGATGGAGTCAGA-3', extension 5'-ATTATAATCAATGATGATTGAAGTAACTGCACGAAATTTGA GG-3'; forward 5'-GCAAAGTCCTCACTGGGAGGA-3', reverse 5'-GGGCTGCGATGGAGTCAGA-3', extension 5'-ATCAATGATGATCCAGGCAGTCTACAAC AGCC-3'; forward 5'-AATGACGACCTAAGCTGCAC-3', reverse 5'-TTGATAAATCTTTGTTGGAGGGTG-3', extension 5'-TCATGATTATAATCAATGATGATTTCCCCCTAGTTGTGTCTTGC-3', respectively. $\mathrm{PCR}$ was performed in a mixture containing $1.25 \mathrm{pmol}$ of each primer, $50 \mathrm{ng}$ of genomic DNA, $250 \mu \mathrm{M}$ dNTPs, and $0.15 \cup$ Taq DNA Polymerase (Applied Biosystems, Foster City, CA) in a buffer provided by the manufacturer. Amplification was performed in a GeneAmp PCR System 9700 thermal cycler (Applied Biosystems) under touchdown conditions (Don et al., 1991).

To clean up the PCR reaction for the primer extension reaction, one unit of Shrimp Alkaline Phosphatase (SAP; Amersham Life Sciences, Cleveland, $\mathrm{OH})$ and two units of Exo I (Amersham Life Sciences) were added to the PCR products. The mixture was incubated for $1 \mathrm{~h}$ at $37^{\circ} \mathrm{C}$ and $15 \mathrm{~min}$ at $72^{\circ} \mathrm{C}$ to inactivate the enzymes.

Primer extension reactions were performed using a SNaPshot ddNTP Primer Extension Kit (Applied Bio- 
systems). To clean up the primer extension reaction, one unit of SAP was added to the reaction mixture and the mixture was incubated at $37^{\circ} \mathrm{C}$ for $1 \mathrm{~h}$, followed by $15 \mathrm{~min}$ at $72^{\circ} \mathrm{C}$ for enzyme inactivation. The DNA samples, containing extension products, and $\mathrm{Ge}$ nescan 120 Liz size standard solution was added to $\mathrm{Hi}-\mathrm{Di}$ formamide (Applied Biosystems) according to the manufacturer's recommendations. The mixture was incubated at $95^{\circ} \mathrm{C}$ for $5 \mathrm{~min}$, placed on ice for $5 \mathrm{~min}$ and then electrophoresed using an $\mathrm{ABI}$ Prism 3100 Genetic Analyzer. The results obtained were analyzed using $\mathrm{ABI}$ Prism GeneScan and Genotyper program (Applied Biosystems).

\section{Statistics}

The $x^{2}$ test was used to compare the observed numbers of each genotype with those expected for a population complying with the Hardy-Weinberg equilibrium. Heterozygosity for each locus with allele frequencies $p$ and $q=1-p$ is given by $H=1 \cdot p^{2} \cdot q^{2}=$ $2 p(1-p)$. Widely used measures of linkage disequilibrium (LD) between all pairs of biallelic loci, Lewontin's D' (|D'|) and the measure $d^{2}$ (Hedrick, 1987) were calculated. Odds ratios with a $95 \%$ confidence interval and $P$ values of logistic regression models, after controlling for the effects of age (continuous values) and

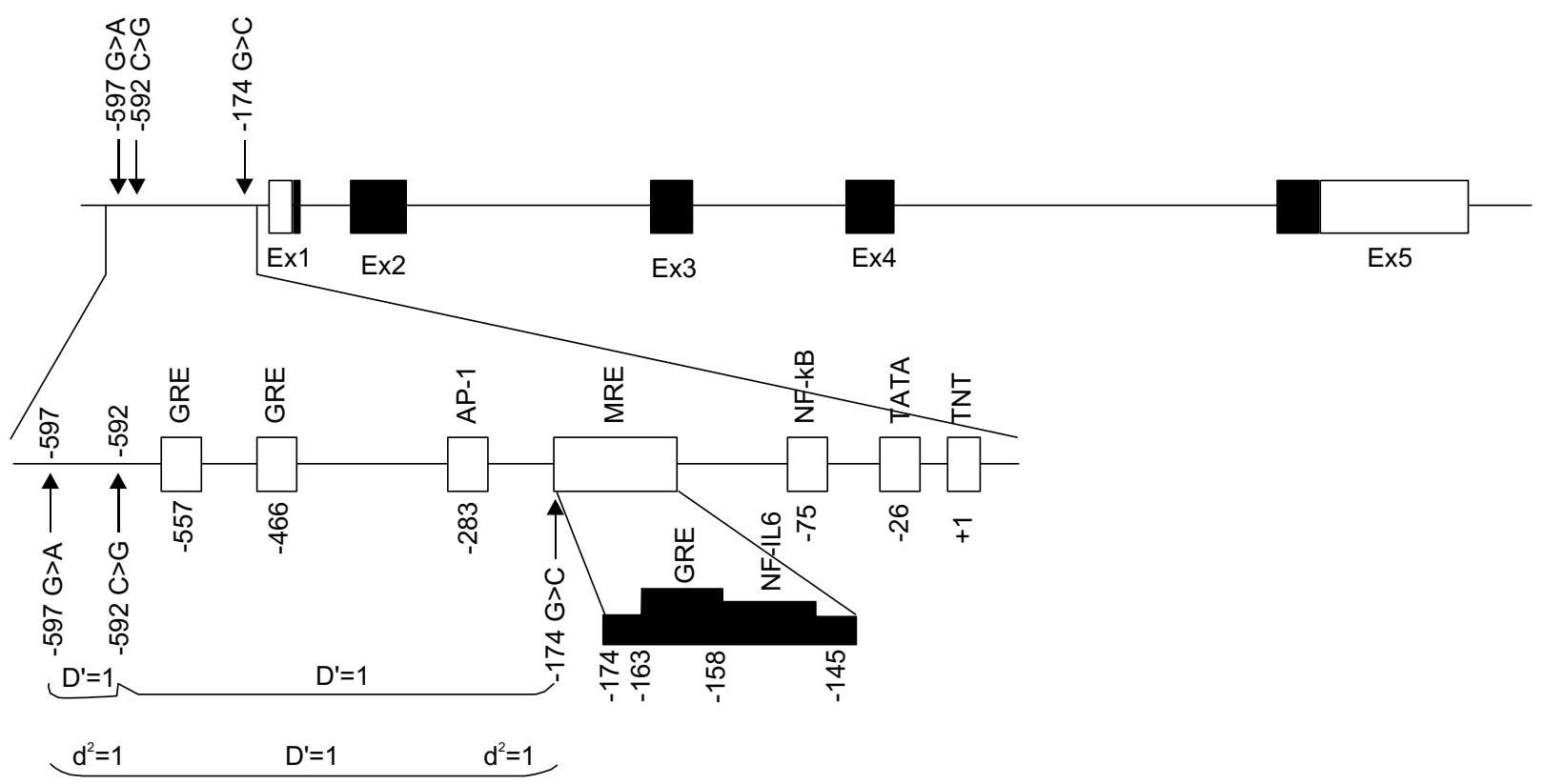

Figure 1. Map of human IL6 on chromosome 7p21. Exons, UTR, and SNPs are shown with the putative transcriptional factor-binding site. Coding exons are marked by shaded blocks and $5^{\prime}$ and $3^{\prime}$ UTR by white blocks. The first base of the transcriptional start site is denoted nucleotide +1 . The values of $D^{\prime}$ and $d^{2}$ between SNPs are also shown (See text).

Table 2. SNPs of the human IL6 promoter and frequencies in the Korean population.

\begin{tabular}{|c|c|c|c|c|c|c|}
\hline Locus & SNP site $^{a}$ & & Genotyp & & Frequency $^{\mathrm{b}}$ & Heterozygosity \\
\hline \multirow[t]{2}{*}{ IL6-597 G>A } & -597 & $A$ & $A G$ & G & 0.002 & 0.005 \\
\hline & & 0 & 5 & 1019 & & \\
\hline \multirow[t]{2}{*}{ IL6-572 C >G } & -572 & $G$ & $\mathrm{G} / \mathrm{C}$ & C & 0.25 & 0.375 \\
\hline & & 62 & 371 & 557 & & \\
\hline \multirow[t]{2}{*}{ IL6-174 G >C } & -174 & $C$ & $\mathrm{G} / \mathrm{C}$ & G & 0.002 & 0.005 \\
\hline & & 0 & 5 & 1032 & & \\
\hline
\end{tabular}

${ }^{a}$ Calculated from the transcriptional start site. ${ }^{b}$ Frequencies of rare alleles. Genotype distributions in all loci were in Hardy-Weinberg equilibrium $(P>0.05)$. IL6-597 $G>A$ and IL6-174 $G>C$ are in absolute LD $\left(d^{2}=1\right)$. IL6-572 $C>G$ was in complete $L D\left(D^{\prime}=1\right)$ with IL6-597 $G>A$ and IL6-174 G >C. For the calculation of allele frequencies, HBsAg negative individuals in cohort are also included. 
sex, were computed. Cox models were used to calculate the relative hazards and $P$ values to evaluate the effects of genotypic variables on the time interval to $\mathrm{HCC}$ after HBV infection adjusted by gender.

\section{Results}

\section{Allele and haplotype frequencies of IL6 promoter SNPs}

The allele frequencies of the SNPs in Korean population were; 0.002 (IL6-597 G>A), 0.25 (IL6-572 C $>\mathrm{G}$ ) and 0.002 (IL6-174 G >C) (Table 2). Genotype distributions were in Hardy-Weinberg equilibrium $(P>$ 0.05). IL6-597 G $>A$ and IL6-174 G $>C$ were found to be totally linked together and to have showed very low allele frequencies (0.002). These SNPs are commonly found in Caucasians (0.4-0.44). On the other hand, the frequency of $C$ allele of IL6-572 $C>G$ was

Table 3. IL6 promoter haplotypes and their frequencies in Korean population $(n=1,046)$ with three IL6 promoter SNPs (IL6-597 G $>$ A: IL6-572 C > G: IL6-174 G>C).

\begin{tabular}{ccccc} 
& \multicolumn{2}{c}{ SNPs in } & IL6 promoter & \\
Haplotype & Frequency \\
\cline { 2 - 3 } & IL6-597 & IL6-572 & IL6-174 & \\
& G $>$ A & C $>$ G & G $>$ C & \\
\hline GCG & G & C & G & 0.758 \\
GGG & G & G & G & 0.240 \\
AGC & A & G & C & 0.002
\end{tabular}

${ }^{a}$ Haplotypes were constructed by pair-wise tables of three loci. There was no ambiguous haplotype phasing due to absolute $\operatorname{LD}\left(d^{2}=1\right)$ and complete $L D\left(\left|D^{\prime}\right|=1\right)$ between SNPs. To calculate haplotype frequencies, $\mathrm{HBsAg}$ negative individuals were also included in the cohort. much higher (0.75) than reported in a Caucasian population (0.06) (Terry et al., 2000). Only 3 haplotypes were observed out of 8 possible haplotypes; these frequencies are shown in Table 3. The genotype combinations were phased without any ambiguity. Two major haplotypes were found to account for more than $99 \%$ of three haplotypes observed.

\section{Analysis for linkage disequilibrium}

IL6-597 G $>A$ and IL6-174 G $>C$ were in absolute LD $\left(D^{\prime}=1, d^{2}=1\right)$, and they had identical allele frequencies, with only two of the four possible haplotypes (A-C and G-G); i.e. the allele at IL6-597 G > A was found to occur only with the $C$ allele at IL6-174 $\mathrm{G}>\mathrm{C}$ and the $\mathrm{G}$ allele at IL6-597 $\mathrm{G}>\mathrm{A}$ to occur only with the $G$ allele at IL6-174 $G>C$, as indicated by a $d^{2}$ value of one. IL6-597 $\mathrm{G}>\mathrm{A}$ and IL6-174 $\mathrm{G}>\mathrm{C}$ had the same $L D\left(D^{\prime}=1\right.$, complete $\left.L D\right)$ with IL6-572 $C>G$; only three of the four possible haplotypes were observed in the population.

\section{Association analysis with chronic hepatitis $B$ outcome}

The loci, IL6-597 G>A and IL6-174 G>C were not analyzed statistically because of their allele frequencies in the population were too low. IL6 haplotypes were not analyzed because they had almost the same distributions (>99.9\%) as IL6-572 C > G. IL6-572 C> $G$ associations with chronic HBV infection outcome were analyzed in a Korean chronic hepatitis B cohort. The results of the statistical analysis are summarized in Tables 4 and 5. Allele frequencies were compared for; i) patients with $\mathrm{CH}$ and chronic carriers vs. chronic hepatis patients those with clinical evidence

Table 4. Analysis for two different phenotypes in the progression to hepatocellular carcinoma (HCC); i) occurrence of LC vs. no LC occurrence based on $\mathrm{CH}$ and ii) occurrence of $\mathrm{HCC}$ versus No HCC based on LC as functions of IL6-572 C> G.

\begin{tabular}{|c|c|c|c|c|c|c|c|c|c|}
\hline \multirow{2}{*}{ Locus } & \multirow{2}{*}{ Genotype } & \multicolumn{4}{|c|}{$\mathrm{LC}$ occurrence on $\mathrm{CH}$} & \multicolumn{4}{|c|}{ HCC occurrence on LC } \\
\hline & & $\begin{array}{c}\text { LC } \\
N(\%)\end{array}$ & $\begin{array}{l}\text { No-LC } \\
\text { N (\%) }\end{array}$ & $\mathrm{OR}^{\mathrm{a}}(95 \% \mathrm{Cl})$ & $P^{a}$ & $\begin{array}{c}\mathrm{HCC} \\
\mathrm{N}(\%)\end{array}$ & $\begin{array}{c}\text { No-HCC } \\
N(\%)\end{array}$ & $\mathrm{OR}^{\mathrm{a}}(95 \% \mathrm{Cl})$ & $P^{\mathrm{a}}$ \\
\hline \multirow[t]{3}{*}{$\begin{array}{l}I L 6-572 \\
\quad C>G\end{array}$} & $\mathrm{C}$ & $\begin{array}{c}391 \\
(69.1 \%)\end{array}$ & $\begin{array}{c}175 \\
(30.9 \%)\end{array}$ & 1.0 & & $\begin{array}{c}117 \\
(53 \%)\end{array}$ & $\begin{array}{c}274 \\
(57.7 \%)\end{array}$ & 1.0 & \\
\hline & GC & $\begin{array}{c}261 \\
(74.8 \%)\end{array}$ & $\begin{array}{c}88 \\
(25.2 \%)\end{array}$ & $\begin{array}{c}1.27 \\
(0.94-1.73)\end{array}$ & 0.13 & $\begin{array}{c}92 \\
(41.6 \%)\end{array}$ & $\begin{array}{c}169 \\
(35.6 \%)\end{array}$ & $\begin{array}{c}1.04 \\
(0.56-1.95)\end{array}$ & 0.89 \\
\hline & G & $\begin{array}{c}44 \\
(72.1 \%)\end{array}$ & $\begin{array}{c}17 \\
(27.9 \%)\end{array}$ & $\begin{array}{c}1.06 \\
(0.78-1.43)\end{array}$ & 0.71 & $\begin{array}{c}12 \\
(5.4 \%)\end{array}$ & $\begin{array}{c}32 \\
(6.7 \%)\end{array}$ & $\begin{array}{c}1.23 \\
(0.57-2.69)\end{array}$ & 0.60 \\
\hline
\end{tabular}

${ }^{a}$ Odds ratio $(95 \% \mathrm{Cl})$ and $P$ value calculated by difference of allele frequency between each group. The homozygotes for common alleles were used as referent to heterozygotes and homozygotes of rare allele. Statistical analysis. Logistic regression models were used to calculate the odds ratios (95\% confidence interval) and corresponding $P$ values for IL6-572 G>C controlling age (continuous) and sex as covariates. Age was highly associated with the occurrence of LC and HCC $(P<0.0001)$ as expected. Sex was associated with the occurrence of HCC based on LC $(P=0.0004)$. All patients included in this study were HBsAg positive. 
Table 5. Survival analysis of time to HCC after HBV infection as functions of IL6-572 $\mathrm{G}>\mathrm{C}$.

\begin{tabular}{llllll}
\hline Locus $^{\mathrm{a}}$ & Models & $\mathrm{N}$ & Events & $\mathrm{P}$ & $\mathrm{RH}$ \\
\hline IL6-572 C $>\mathrm{G}$ & Co-dominant & 1,028 & 226 & 0.62 & 0.95 \\
& Dominant & & & 0.90 & 1.02 \\
& Recessive & & & 0.17 & 0.66 \\
\hline
\end{tabular}

${ }^{a} / L 6-597 \mathrm{G}>\mathrm{A}, I L 6-174 \mathrm{G}>\mathrm{C}$ and IL6 haplotypes were not analyzed due to low frequencies in the Korean population.

Statistical analysis. Cox models were used for calculating relative hazards and $P$ values for $I L 6-572 \quad C>G$ after controlling for age (adjusted age groups; <40, 40-60 and >60) and sex. Most patients in HBV endemic areas, such as Korea, acquire HBV virus vertically, and it progress to HCC after a period of persistent chronic disease (See text). Here, we used the variable 'time to $\mathrm{HCC}^{\prime}$ on the assumption of early infection.

of LC (i.e., portal hypertension), ii) cirrhotic patients with $\mathrm{HCC}$ vs. without HCC by logistic regression, and iii) the time interval from the onset of infection to HCC were analyzed by Cox relative hazard analysis, on the assumption that all the patients were infected during early infancy. No significant associations were detected between IL6-572 C > G and hepatitis B outcome; i.e., LC occurrence on $\mathrm{CH}(\mathrm{OR}=1.27, P=$ $0.13 ; \mathrm{OR}=1.06, P=0.71)$ and $\mathrm{HCC}$ occurrence on LC $(\mathrm{OR}=1.04, P=0.89$; OR=1.23, $P=0.60)$ of heterozygotes and homozygotes for $G$ allele in referent comparison to homozygotes for common genotype (C/C genotype), and time interval to $\mathrm{HCC}(\mathrm{RH}=0.67-$ $1.00 ; P=0.14-0.99$ )

\section{Discussion}

The different outcomes of HBV infection might be explained by virus-host interactions (Cruz et al., 1987). However, little is known about the host genetic factors that are involved in the progress of HBV infection. IL6 is one of the candidate genes, which might influence the outcome of chronic liver disease. Elevated IL6 levels were detected in chronic liver disease (Sekiyama et al., 1994; Oyanagi et al., 1999). During HBV infection progress, IL-6 production was reported to be up-regulated by HBV-X in hepatic inflammation (Lee et al., 1998). IL6 is also associated with chronic immune-mediated diseases, such as systemic onset juvenile chronic arthritis (Fishman et al., 1998). Moreover, it is known that differences in the IL6 promoter haplotype may have an important role in determining levels of IL6 gene transcription. The transcriptional control of this gene is complex, and subtle variations in the promoter are known to influence the regulation of this system (Terry et al., 2000).

In the present study, we found a different genetic background in Koreans and Caucasians with respect to the allele frequencies of the IL6 promoter SNPs. The allele frequencies of IL6-174 and IL6-597 reported in Caucasian (0.40-0.45) (Terry et al., 2000; Brull et al., 2001; Burzotta et al., 2001; Cavet et al., 2001; Cox et al., 2001; Fedetz et al., 2001; Helmy et al., 2001; Zhai et al., 2001) are much higher than those found in Koreans in our study $(0.002)$ or in the Chinese population (0.002) (Zhai et al., 2001). On the other hand, the frequency of the $C$ allele of IL6-572 in Caucasians (0.04-0.06) is much lower than those of the Korean (0.75) and Japanese populations (0.816) (Ota et al., 2001). High frequency populationspecific alleles are particularly useful for mapping genes the responsible for disease susceptibility and other traits in a population (Parra et al., 1998; Stephens et al., 2001). The SNP of IL6-572 might be a more useful marker for an association study in Asians than in Caucasians.

LD is becoming an important tool in genetic studies because it is applicable to a variety of topics, including disease-gene mapping (Rannala and Reeve, 2001; Riley et al., 2000). The SNPs in the IL6 promoter region are in strong LD, and only 3 haplotypes were observed out of eight possible haplotypes. Generally, haplotypes are more informative than single SNPs, but IL6 haplotypes in Korean population were no more informative for association study of complex trait diseases than single SNPs due to too low frequencies of IL6-597 $\mathrm{G}>\mathrm{A}$ and IL6-174 $\mathrm{G}>\mathrm{C}$.

In this study, we found that the three haplotypes constructed by the 3 SNPS in the IL6 promoter region, and their frequencies in the Korean population, and variants in the IL6 gene are not associated with subsequent HBV outcomes, though elevated IL6 levels have been detected in several studies and have been found to functionally significant in other diseases. In conclusion, this study shows that although IL6 may have important functions in the progress of chronic HBV infection, that its' genetic variants probably do not influence the development of LC and HCC from chronic HBV infection.

\section{Acknowledgement}

This work was supported by the 21C Frontier Functional Human Genome Project (grant number FG4-16) operated under the auspices of the Korean Ministry of Science and Technology.

\section{References}

Almarri A, Batchelor JR. HLA and hepatitis B infection. Lancet 1994;344(8931):1194-5

Bellamy R, Ruwende C, Corrah T, McAdam KP, Thursz M, Whittle HC, Hill AV. Tuberculosis and chronic hepatitis B 
virus infection in Africans and variation in the vitamin $D$ receptor gene. J Infect Dis 1999;179(3):721-4

Blumberg BS. Hepatitis B virus and the control of hepatocellular carcinoma. IARC Sci Publ 1984;63:243-61

Brull DJ, Montgomery HE, Sanders J, Dhamrait S, Luong L, Rumley A, Lowe GD, Humphries SE. Interleukin- 6 gene $-174 \mathrm{G}>\mathrm{C}$ and $-572 \mathrm{G}>\mathrm{C}$ promoter polymorphisms are strong predictors of plasma interleukin-6 levels after coronary artery bypass surgery. Arterioscler Thromb Vasc Biol 2001; 21(9):1458-63

Burzotta F, lacoviello L, Di Castelnuovo A, Glieca F, Luciani N, Zamparelli R, Schiavello R, Donati MB, Maseri A, Possati $\mathrm{G}$, Andreotti $\mathrm{F}$. Relation of the $-174 \mathrm{G} / \mathrm{C}$ polymorphism of interleukin-6 to interleukin-6 plasma levels and to length of hospitalization after surgical coronary revascularization. Am J Cardiol 2001;88(10):1125-8

Cacciola I, Cerenzia G, Pollicino T, Squadrito G, Castellaneta S, Zanetti AR, Mieli-Vergani G, et al. Genomic heterogeneity of hepatitis B virus (HBV) and outcome of perinatal HBV infection. J Hepatol 2002;36:426-32

Cavet J, Dickinson AM, Norden J, Taylor PR, Jackson GH, Middleton PG. Interferon-gamma and interleukin- 6 gene polymorphisms associate with graft-versus-host disease in HLAmatched sibling bone marrow transplantation. Blood 2001; 98(5):1594-600

Cox ED, Hoffmann SC, DiMercurio BS, Wesley RA, Harlan $D M$, Kirk AD, Blair PJ. Cytokine polymorphic analyses indicate ethnic differences in the allelic distribution of interleukin-2 and interleukin-6. Transplantation 2001;72(4):720-6

Cruz AC, Frentzen BH, Behnke M. Hepatitis B: A case for prenatal screening of all patients. Am J Obstet Gynecol 1987;156(5):1180-3

Don RH, Cox PT, Wainwright BJ, Baker K, Mattick JS. 'Touchdown' PCR to circumvent spurious priming during gene amplification. Nucleic Acids Res 1991;19(14):4008

Fedetz M, Matesanz F, Pascual M, Martin J, Fernandez O, Guerrero M, Alcina A. The -174/-597 promoter polymorphisms in the interleukin- 6 gene are not associated with susceptibility to multiple sclerosis. J Neurol Sci 2001; 190(1-2):69-72

Fishman D, Faulds G, Jeffery R, Mohamed-Ali V, Yudkin JS, Humphries S, Woo P. The effect of novel polymorphisms in the interleukin-6 (IL-6) gene on IL-6 transcription and plasma IL-6 levels, and an association with systemic-onset juvenile chronic arthritis. J Clin Invest 1998;102(7):1369-76

Galun E, Nahor O, Eid A, Jurim O, Rose-John S, Blum HE, Nussbaum O, llan E, Daudi N, Shouval D, Reisner Y, Dagan S. Human interleukin-6 facilitates hepatitis $B$ virus infection in vitro and in vivo. Virology 2000;270(2):299-309

Hedrick PW. Gametic disequilibrium measures: proceed with caution. Genetics 1987;117(2):331-41

Helmy N, Maly FE, Bestmann L. Detection of the single-base substitution $-174 \mathrm{G} \rightarrow \mathrm{C}$ in the interleukin- 6 gene by real-time polymerase chain reaction: comment on the article by Moos et al. Arthritis Rheum 2001;44(9):2213-4

Huh K, Choi SY, Whang YS, Lee DS. Prevalence of viral hepatitis markers in Korean patients with hepatocellular carcinoma. J Korean Med Sci 1998;13(3):306-10

Kakumu S, Shinagawa T, Ishikawa T, Yoshioka K, Wakita $\mathrm{T}$, Ida N. Interleukin 6 production by peripheral blood mononuclear cells in patients with chronic hepatitis $B$ virus infection and primary biliary cirrhosis. Gastroenterol Jpn 1993;28(1):18-24

Lee HS, Han CJ, Kim CY. Predominant etiologic association of hepatitis $C$ virus with hepatocellular carcinoma compared with hepatitis B virus in elderly patients in a hepatitis B-endemic area. Cancer 1993;72:2564-7

Lee Y, Park US, Choi I, Yoon SK, Park YM, Lee YI. Human interleukin 6 gene is activated by hepatitis $B$ virus- $X$ protein in human hepatoma cells. Clin Cancer Res 1998;4(7):1711-7

Malaguarnera M, Di Fazio I, Laurino A, Ferlito L, Romano $M$, Trovato BA. Serum interleukin 6 concentrations in chronic hepatitis $C$ patients before and after interferon-alpha treatment. Int J Clin Pharmacol Ther 1997;35(9):385-8

Merican I, Guan R, Amarapuka D, Alexander MJ, Chutaputti A, Chien RN, Hasnian SS, Leung N, Lesmana L, Phiet PH, Sjalfoellah Noer HM, Sollano J, Sun HS, Xu DZ. Chronic hepatitis B virus infection in Asian countries. J Gastroenterol Hepatol 2000;15(12):1356-61

Ota N, Nakajima T, Nakazawa I, Suzuki T, Hosoi T, Orimo $\mathrm{H}$, Inoue $\mathrm{S}$, Shirai $\mathrm{Y}$, Emi M. A nucleotide variant in the promoter region of the interleukin- 6 gene associated with decreased bone mineral density. J Hum Genet 2001;46(5): 267-72

Oyanagi Y, Takahashi T, Matsui S, Takahashi S, Boku S, Takahashi K, Furukawa K, Arai F, Asakura H. Enhanced expression of interleukin-6 in chronic hepatitis C. Liver 1999;19(6):464-72

Parra EJ, Marcini A, Akey J, Martinson J, Batzer MA, Cooper R, Forrester T, Allison DB, Deka R, Ferrell RE, Shriver MD. Estimating African American admixture proportions by use of population-specific alleles. Am J Hum Genet 1998;63(6): 1839-51

Rannala B, Reeve JP. High-resolution multipoint linkage-disequilibrium mapping in the context of a human genome sequence. Am J Hum Genet 2001;69(1):159-78

Riley JH, Allan CJ, Lai E, Roses A. The use of single nucleotide polymorphisms in the isolation of common disease genes. Pharmacogenomics 2000;1(1):39-47

Sekiyama KD, Yoshiba M, Thomson AW. Circulating proinflammatory cytokines (IL-1 beta, TNF-alpha, and IL-6) and IL-1 receptor antagonist (IL-1Ra) in fulminant hepatic failure and acute hepatitis. Clin Exp Immunol 1994;98(1):71-7

Shimbo S, Zhang ZW, Qu JB, Wang JJ, Zhang CL, Song LH, Watanabe T, Higashikawa K, Ikeda M. Urban-rural comparison of HBV and HCV infection prevalence among adult women in Shandong Province, China. Southeast Asian J Trop Med Public Health 1997;28(3):500-6

Song W, Zhang F, Li Z. A quantitative analysis of IL-6 mRNA expression of peripheral blood monocyte cell in patients with chronic hepatitis B. Zhonghua Gan Zang Bing Za Zhi 2000;8(6):346-7

Stephens JC, Schneider JA, Tanguay DA, Choi J, Acharya $\mathrm{T}$, Stanley SE, Jiang R, Messer CJ, Chew A, Han JH, Duan 
J, Carr JL, Lee MS, Koshy B, Kumar AM, Zhang G, Newell WR, Windemuth A, Xu C, Kalbfleisch TS, Shaner SL, Arnold K, Schulz V, Drysdale CM, Nandabalan K, Judson RS, Ruano G, Vovis GF. Haplotype variation and linkage disequilibrium in 313 human genes. Science 2001;293(5529): 489-93

Terry CF, Loukaci V, Green FR. Cooperative influence of genetic polymorphisms on interleukin 6 transcriptional regulation. J Biol Chem 2000;275(24):18138-44

Thursz M. Genetic susceptibility in chronic viral hepatitis. Antiviral Res 2001;52(2):113-6

Thursz MR. Host genetic factors influencing the outcome of hepatitis. J Viral Hepat 1997;4(4):215-20

Wang JY, Wang XL, Liu P. Detection of serum TNF-alpha, IFN-beta, IL-6 and IL-8 in patients with hepatitis B. World
J Gastroenterol 1999;5(1):38-40

Yu H, Harris RE, Kapat GC, et al. Cigarette smoking, alcohol consumption, and primary liver cancer: A case-control study in the USA. Int J Cancer 1988;42:325-8

Yu MC, Yuan JM, Govindarajan S, Ross RK. Epidemiology of hepatocellular carcinoma. Can J Gastroenterol 2000a; 14(8):703-9

Yu MW, Pai Cl, Yang SY, Hsiao TJ, Chang HC, Lin SM, Liaw YF, Chen PJ, Chen CJ. Role of N-acetyltransferase polymorphisms in hepatitis B related hepatocellular carcinoma: impact of smoking on risk. Gut 2000b;47(5):703-9

Zhai R, Liu G, Yang C, Huang C, Wu C, Christiani DC. The $G$ to $C$ polymorphism at -174 of the interleukin- 6 gene is rare in a Southern Chinese population. Pharmacogenetics 2001;11(8):699-701 